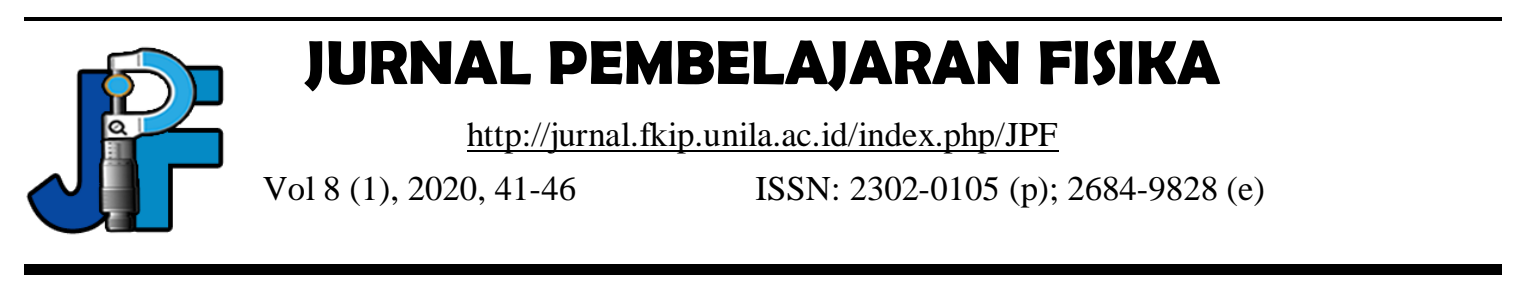

\title{
Implementation of Science Story Media Etnosains Based to Boost Students Concept and Scientific Attitudes
}

\author{
Rahma $^{1 *}$, Nanda Safarati $^{1}$ \\ ${ }^{1}$ Universitas Almuslim' Bireuen, Indonesia \\ *e-mail: rahma@umuslim.ac.id
}

\begin{abstract}
This research aims to produce an ethnics-based science story media to foster understanding of scientific concepts and attitudes, especially on a material equilibrium of rigid bodies. This type of research is one group pretest and posttest design. The results of this study indicate that the $\mathrm{N}$-gain understanding of concepts in the experimental class $(\mathrm{g}=0.69)$ is higher than the control class $(g=0.08)$, as well as the results of the analysis of scientific attitudes of students in the experimental class $(g=0.73)$ higher than the control class $(g=0.08)$. Also, there was a significant difference in the average test results of students' understanding of concepts and scientific attitudes $(\mathrm{p}<0.05)$ between the experimental class and the control class. The conclusion is the use of ethnics-based science story media can improve students' understanding of scientific concepts and attitudes.
\end{abstract}

Keywords: ethnics, scientific attitude, science story, understanding of concepts

DOI: http://dx.doi.org/10.23960/jpf.v8.n1.202005 


\section{INTRODUCTION}

The development of education in Indonesia cannot be separated from the demand to master the increasingly sophisticated science and technology, both in terms of teachers and students. In this era of globalization, many positive and negative things that indirectly have an impact on the sustainability of education in Indonesia. One positive impact is the creation of learning media both manually and online media. The Government optimizes national education goals by trying to perfect the existing curriculum, the 2013 curriculum by applying a scientific approach. Relation to the concept of learning physics knowledge obtained through data collection by experimentation, observation, and deduction to produce an explanation of a phenomenon that can be trusted (Widiyatmoko \& Pamelasari, 2012). Learning physics is considered important because it is considered as one of the sciences that plays an important role in the development of science and technology to meet the demands of the 21 st century or "Essential 21Century Skills" where humans are required to be able to think creatively and think critically to solve a problem (problem-solving), innovate, collaborating and communicating (Permendikbud Nomor 58 Tahun 2014).

Observation during the learning process although science process skills do not have an influence understanding concepts Science students, interactions between science process skills and attitudes science have a positive influence on understanding students' science concepts so deep science process skills learning should be done in a manner simultaneous with scientific attitude as one effort to improve understanding students' science concepts (Putra et al., 2015). In the current learning process, students are required to fulfil three main integrated components, namely attitudes, knowledge, and skills. The scientific approach to learning as referred to includes observing, asking, reasoning, trying, and communicating it. Students are directed to be more active in learning, while educators act as facilitators and motivators. Learning in schools, especially physics, is still studied in a textbook not contextually by exploring the cultural potentials that exist in the surrounding environment. This causes the students' thinking patterns to be limited and weakening the understanding of physics concepts and scientific attitudes of students. Therefore, in preparing the learning experience for students the teacher should not only emphasize the product but also the aspects of the process, attitudes, and relevance to everyday life(S. E. Atmojo, 2012). This is relevant to the nature of learning ethics based on recognition of culture as a fundamental (fundamental and important) part of education as an expression and communication of ideas and knowledge development (Ryan, 1978). Appreciation is an understanding and appreciation for an art or culture and weighing a value, feeling that the object is good and understanding why it is good (Sukmadinata, 2010). Development of self instruments assessment and peer assessment to assess scientific attitudes and process skills within learning science with a scientific approach that is reliable, appropriate, useful and easy for use (Kotimah et al., 2015)

Based on the results of a preliminary study in SMA N 1 Peusangan, data analysis of the needs of $78 \%$ of students found it difficult to understand the rigid object's equilibrium material. Also, as many as $80 \%$ of teachers answered that the Solid Object Equilibrium material was likely to use ethnoscience. Each region in Indonesia has different customs and traditions in the culture of the community. (Setyo Eko 
Atmojo, 2018) Aceh is one of the regions that have a culture and customs that are inherent in the lives of its people. The existence of norms, customs, and beliefs in a community in Aceh are all related to balance. To create a harmonious relationship between the people of Aceh, both in natural management and in social relations.

These customs can be noted through the culture (heritage) left by the Acehnese people (Ernita et al., 2013). Seeing this connection, culture is a control mechanism for community behaviour in Aceh. In answering these problems, learning about ethicsrelated science is believed to be able to change learning from teacher-centred learning to student-centred learning, creating contextual and meaningful learning. Ethnographic science-based learning that links learning with community culture will increase students' appreciation of the culture of the community to foster an understanding of scientific concepts and attitudes of students.

\section{METHOD}

This test sheet includes the student pre-test and post-test sheets. The results of student pre-test and post-test were analyzed for improvement using the $n$-gain test. This study aims to improve students' understanding of scientific concepts and attitudes through the use of ethnics-based science story media.

\section{Research Design \& Procedures}

This study uses one group research design pre-test and post-test design with the research instrument used in the form of a test sheet. This test sheet includes the student pre-test and post-test sheets.

One advantage Pre Test-Post Test design) according to Nazir (2003), namely: Pros: because there are exams before they are finished, and there are post-test after approval, it can be done on variables excluded from the same experimental group. Being biased selection variable mortality (lost or dead) can be eliminated with that guarantee The second test is all experimental units. Weaknesses: internal validation is considered lacking, this is considered non-existent The difference between $\mathrm{O}_{1}$ and $\mathrm{O}_{2}$ is always proven by expertise $\mathrm{X}$ (collage skills with fine motor skills).

\section{Population and Sample}

Population is all members of groups of people, animals, events, or objects that live together in a place and by becoming the target of conclusions from the final results of a study. The population can consist of teachers, students, curriculum, school institutions, school and community relations, company employees and so on (Sukardi, 2009). This research was conducted at SMA Negeri 1 Peusangan for class XI students who can accommodate 52 students.

Samples are part of the population (Sukardi, 2009). The sampling method in this study used the Random Sampling technique, the subjects of this study were students of class XI2 and class XI3 students who received 26 students in each class and consisted of 12 men and 14 women for class XI2, class XI3 students and 10 boys and 16 girls.

\section{Data Collection and Instrument}

For research with human objects that are discussed include variables related to humans, the test is a measuring tool that is often used in the fields of educational 
research, psychology, and sociology. With tests, a researcher can measure the desired construct (Sukardi, 2009).

The research instrument used in this study consisted of a test sheet. Data collection techniques through giving tests. This test sheet is published pre-test and posttest students.

\section{Data Analysis}

The results of student pre-test and post-test were analyzed for improvement using the N-gain test. This study aims to improve students' understanding of scientific concepts and attitudes through the use of ethnics-based science story media.

\section{RESULT AND DISCUSSION}

\section{RESULT}

\section{Understanding Concept}

Through learning using ethnics-based science story media on rigid objects equilibrium material. Learning outcomes data on aspects of understanding concepts before and after learning in the form of pretest and posttest. Student learning outcomes in the aspect of understanding concepts are obtained by distributing pretest questions and posttest questions consisting of 15 multiple choice questions and 5 descriptive questions. Assessment Of Student Learning Outcomes On This Aspect Of Knowledge Is Carried Out By Following The Assessment Rubric That Has Been Made. Mastery Of Student Learning Outcomes Is Determined Based On The Applicable Minimum Mastery Criteria (KKM) Of 75. Students Are Categorized As Complete In Learning Compilation Of Appropriate Scores Or Above The Applicable KKM. Completeness Of Student Learning Outcomes Using Group-Based Science Story Media Can Be Seen In The Picture Below

Figure 1. Comparison of Completeness Charts Pretest and Posttest Student Learning Outcomes Aspects of Understanding Concepts

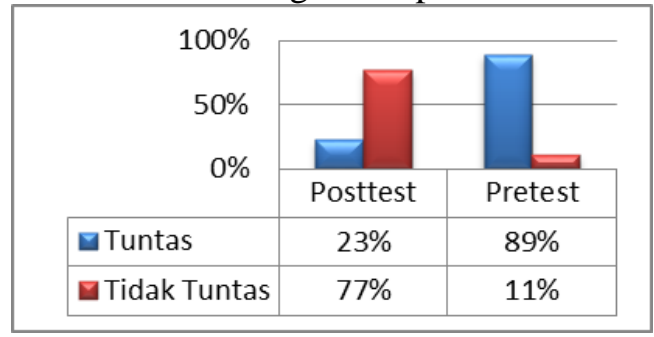

Table 1. N-gain analysis result

\begin{tabular}{ccccc}
\hline Category & \multicolumn{2}{l}{ Control Class } & \multicolumn{2}{c}{ Experimental Class } \\
\cline { 2 - 5 } & Total & Percentage & Total & Percentage \\
& students & $(\%)$ & students & $(\%)$ \\
High & 8 & 31 & 18 & 69 \\
Medium & 6 & 23 & 6 & 23 \\
Low & 12 & 46 & 2 & 8 \\
Amount & 26 & 100 & 26 & 100 \\
\hline
\end{tabular}


Based on the graph above it can be seen that the average percentage of scores obtained at the pretest is $77 \%$ of students with incomplete categories and $23 \%$ complete. After learning with the help of the media, ethnics-based science stories on a material equilibrium of rigid bodies. The average percentage of posttest scores of 26 students was $89 \%$ with the complete category and $11 \%$ with the incomplete category. The results obtained from the pretest and posttest scores showed an increase in the scores obtained by students. Improvement approved by Sugiyono (2016) as in Based on Table 1 it can be seen that the increase in student learning outcomes using ethnics-based science story media, increasing student learning outcomes with a high category there are 18 students with a percentage of $69 \%, 6$ students with a moderate category with a percentage of $23 \%$, and 2 students with a category low with a percentage of $8 \%$ and an average increase of 0.8 in the medium category.

\section{Scientific Attitude}

The results of the analysis, Based on Table 2 can be known as the number of students who have a scientific attitude using ethnics-based science story media, of the 26 students there are 19 students have a high scientific attitude and 7 students have a low scientific attitude.

Table. 1 The number of students who have a scientific attitude is high and low

\begin{tabular}{ccccc}
\hline \multirow{2}{*}{ Category } & \multicolumn{2}{c}{ Control Class } & \multicolumn{2}{c}{ Experimental Class } \\
\cline { 2 - 5 } & Total & Percentage & Total & Percentage \\
students & $(\%)$ & students & $(\%)$ \\
High & 8 & 31 & 19 & 73 \\
Medium & 18 & 69 & 7 & 27 \\
Amount & 26 & 100 & 26 & 100 \\
\hline
\end{tabular}

\section{DISCUSSION}

indicate an increase in grades obtained by students. Increasing student learning outcomes with high categories there are 18 students with a percentage of $69 \%, 6$ students with a moderate category with a percentage of $23 \%$, and 2 students with a low category with a percentage of $8 \%$ and an average increase of 0.8 with a moderate category. The results of the analysis, the number of students who have a scientific attitude using ethnics-based science story media, of the 26 students there are $73 \%$ students have a high scientific attitude and $27 \%$ students have a low scientific attitude.

\section{CONCLUSION}

The conclusion of this study is the understanding of the concept can be improved through ethnoscience-based science story media obtained by $69 \%$ completeness with the medium category. Students who have high scientific attitudes have better affective achievement compared to students who have low scientific attitudes. Whereas cognitive and psychomotor aspects do not affect high scientific attitudes or low scientific attitudes.

\section{REFERENCES}

Atmojo, S. E. (2012). Profil Keterampilan Proses Sains dan Apresiasi Siswa terhadap 
Profesi Pengrajin Tempe dalam Pembelajaran IPA Berpendekatan Etnosains. Jurnal Pendidikan IPA Indonesia. Https://Doi.Org/10.15294/Jpii.V1i2.2128

Atmojo, Setyo Eko. (2018). Pengembangan Perangkat Pembelajaran Ipa Terpadu Berpendekatan Etnosains. Jurnal Pendidikan Sains (JPS). Https://Doi.Org/10.26714/Jps.6.1.2018.5-13

Ernita, A, S., \& M, S. (2013). Penentuan Bagian Tiga Ahli Waris Berdasarkan Manuskrip Tabel Faraidh Menggunakan Metode Kombinatorik, Etnomatematik Dan Etnosains" Seminar Serantau Etnomatematik Malayonesia Ii, Universitas Syiah Kuala. 25-26 Nov.

Kotimah, E., Rosidin, U., \& Wahyudi, I. (2015). Pengembangan Instrumen Assessment Sikap Ilmiah dan Keterampilan Proses Sains dengan Scientific Approach. Jurnal Pembelajaran Fisika Universitas Lampung.

Permendikbud Nomor 58 Tahun 2014. (2014). Kerangka Dasar dan Struktur Kurikulum Sekolah Menengah Pertama/Madrasah Tsanawiyah. British Journal Of Psychiatry. Https://Doi.Org/10.1192/Bjp.205.1.76a

Putra, N., Abdurrahman, A., \& Suana, W. (2015). Pengaruh Keterampilan Proses Sains dan Sikap Ilmiah terhadap Pemahaman Konsep IPA Siswa SMP. Jurnal Pembelajaran Fisika Universitas Lampung.

Ryan, J. M. (1978). Ethnoscience and Problems Of Method In The Social Scientific Study Of Religion. Sociological Analysis. Https://Doi.Org/10.2307/3710444

Metode Penelitian Kuantitatif, Kualitatif, dan R \& D, Alfabeta, Cv. (2016).

Sukardi. (2009). Metodologi Penelitian Pendidikan: Kompetensi dan Praktiknya / Sukardi. In 1. Pendidikan - Metodologi Penelitian,Metodologi Penelitian Pendidikan: Kompetensi Dan Praktiknya / Sukardi. Https://Doi.Org/2009

Widiyatmoko, A., \& Pamelasari, S. D. (2012). Pembelajaran Berbasis Proyek untuk Mengembangkan Alat Peraga IPA dengan Memanfaatkan Bahan Bekas Pakai. Jurnal Pendidikan IPA Indonesia. Https://Doi.Org/10.15294/.V1i1.2013 